\title{
An Archaeological Survey along Leon Creek from Bandera to Babcock Roads, San Antonio, Texas
}

Diane A. Cargill

Center for Archaeological Research

Follow this and additional works at: https://scholarworks.sfasu.edu/ita

Part of the American Material Culture Commons, Archaeological Anthropology Commons, Environmental Studies Commons, Other American Studies Commons, Other Arts and Humanities Commons, Other History of Art, Architecture, and Archaeology Commons, and the United States History Commons

Tell us how this article helped you.

This Article is brought to you for free and open access by the Center for Regional Heritage Research at SFA ScholarWorks. It has been accepted for inclusion in Index of Texas Archaeology: Open Access Gray Literature from the Lone Star State by an authorized editor of SFA ScholarWorks. For more information, please contact cdsscholarworks@sfasu.edu. 
An Archaeological Survey along Leon Creek from Bandera to Babcock Roads, San Antonio, Texas

\section{Creative Commons License}

\section{(c) (1) (8)}

This work is licensed under a Creative Commons Attribution-NonCommercial 4.0 International License 


\section{An Archaeological Survey along Leon Creek from Bandera to Babcock Roads, San Antonio, Texas}

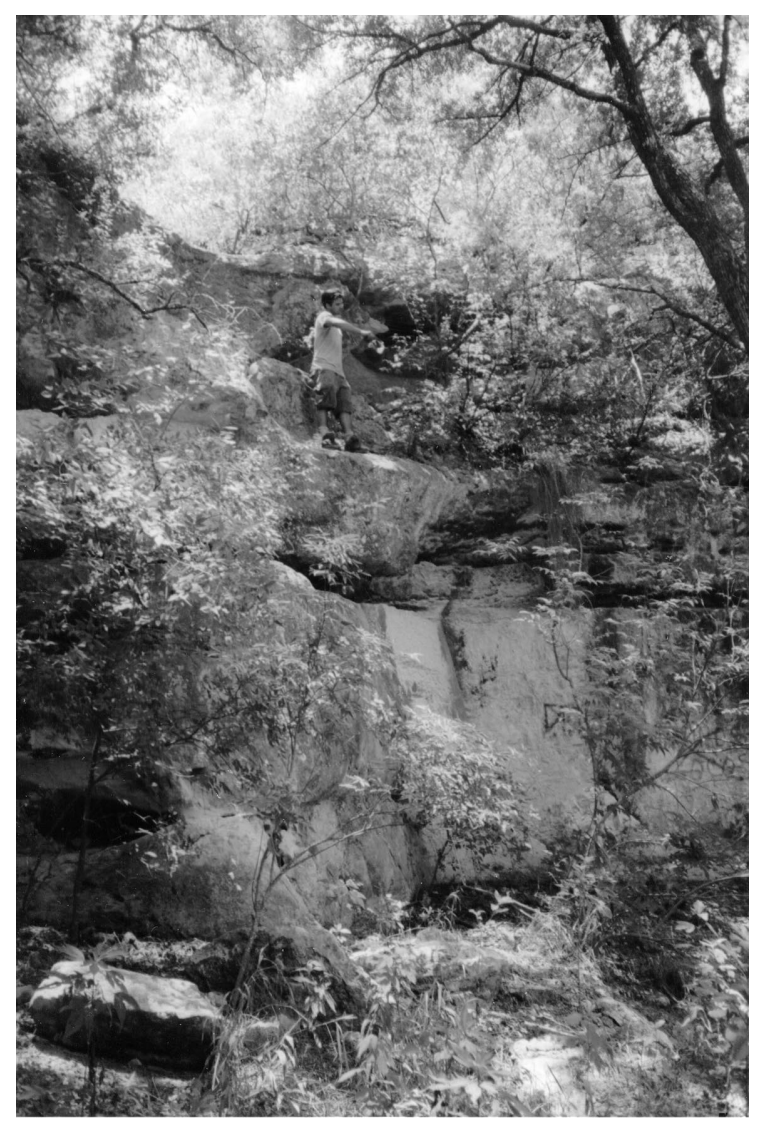

Diane A. Cargill

Center for Archaeological Research The University of Texas at San Antonio Archaeological Survey Report, No. 291 1999

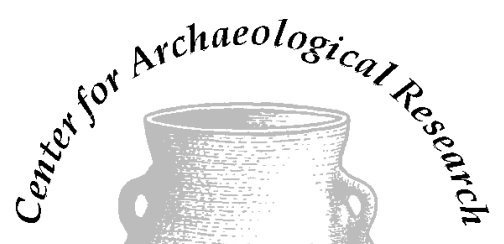

Preserving Cultural Resources

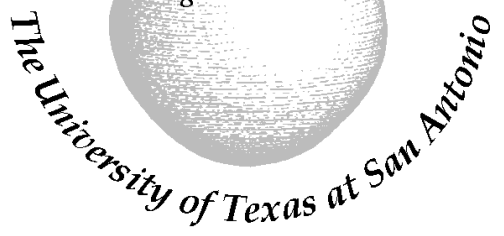




\title{
An Archaeological Survey along Leon Creek from Bandera to Babcock Roads, San Antonio, Texas
}

\author{
Diane A. Cargill
}

\author{
Robert J. Hard and C. Britt Bousman \\ Principal Investigators
}

Texas Antiquities Permit No. 1977

Ccopyright 1999

Center for Archaeological Research

The University of Texas at San Antonio Archaeological Survey Report, No. 291 
The following information is provided in accordance with the General Rules of Practice and Procedure, Chapter 41.11 (Investigative Reports), Texas Antiquities Committee:

1. Type of investigation: Survey

2. Project name: Leon Creek Greenway

3. County: Bexar

4. Principal investigators: Robert J. Hard and C. Britt Bousman

5. Name and location of sponsoring agency: San Antonio City Parks and Recreation Department, 115 Plaza de Armas, Suite 260, San Antonio, Texas 78283-3966

6. Texas Antiquities Permit No.: 1977

7. Published by the Center for Archaeological Research, The University of Texas at San Antonio, 6900 N. Loop 1604 W., San Antonio, Texas 78249-0658, 1999

A list of publications offered by the Center for Archaeological Research is available. Call (210) 458-4378; write to the Center for Archaeological Research, The University of Texas at San Antonio, 6900 N. Loop 1604 W., San Antonio, Texas 78249-0658; e-mail to car@lonestar.utsa.edu; or visit CAR's web site at http://csbs3.utsa.edu/car. 


\begin{abstract}
An archaeological survey was conducted along Leon Creek from Bandera to Babcock roads from July 15 through July 24, and September 14 and 15, 1998, by the Center for Archaeological Research, University of Texas at San Antonio, for the San Antonio Parks and Recreation Department. Three newly identified prehistoric sites were documented within the project area. Sites 41BX1301 and 41BX1303 are not recommended as being eligible for State Archaeological Landmark status nor are they recommended as being eligible for inclusion in the National Register of Historic Places due to the paucity of materials present and to the secondary context in which they were found. The third site, 41BX1302 is located on a T1 terrace of Leon Creek and represents an intact deposit comprised of at least two components, an upper deposit and a buried component. Looting and erosion are disturbing this site and a course of action is strongly recommended to halt the destruction of 41BX1302. It is recommended that 41BX1302 has the potential for State Archaeological Landmark status and for listing in the National Register of Historic Places and that this site should be avoided during the construction of the Leon Creek Greenway. If complete avoidance of 41BX1302 is not possible, testing for site significance is recommended prior to ground-disturbing activities.
\end{abstract}




\section{Contents}

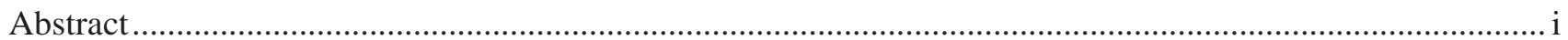

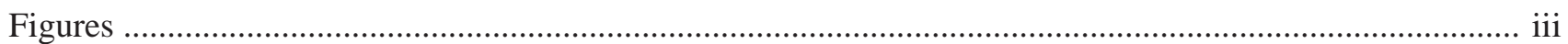

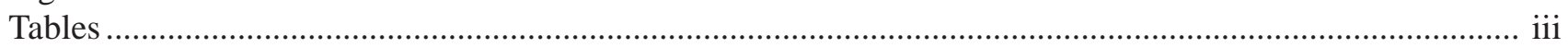

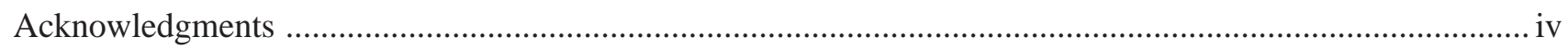

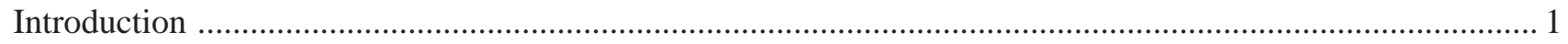

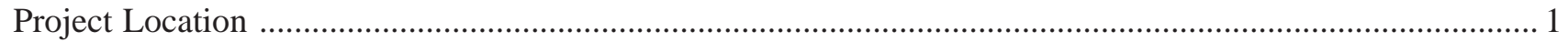

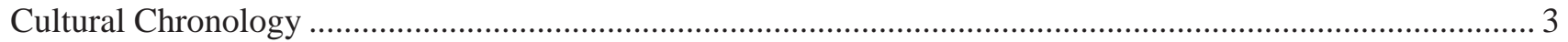

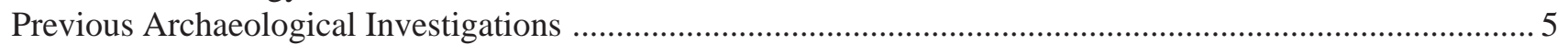

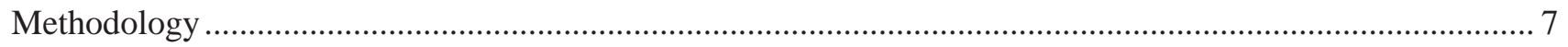

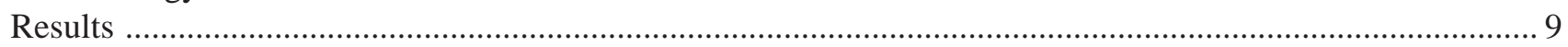

Summary and Recommendations .............................................................................................. 17

Appendix 1. Lithic Analysis of Bifaces, Projectile Points, and Complete Flakes

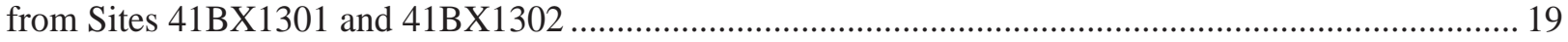

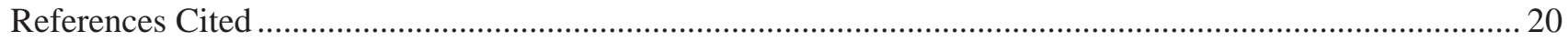




\section{Figures}

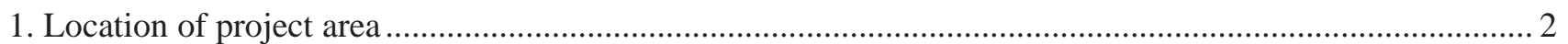

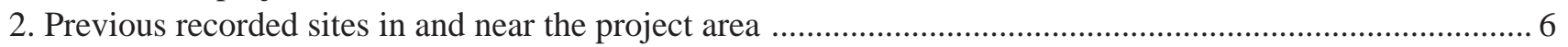

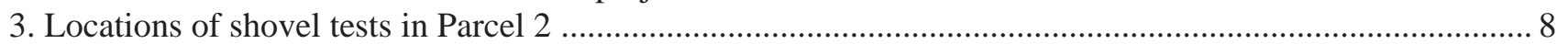

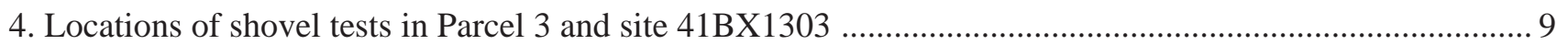

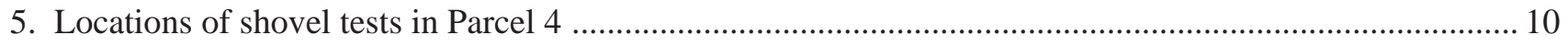

6. Locations of shovel tests in Parcel 5 adn sites 41BX1301 and 41BX1302 ........................................... 10

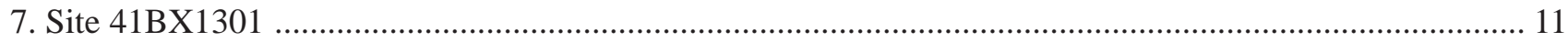

8. Site 41BX1302 showing shovel tests, erosional feature, buried component, and looters' holes ................. 13

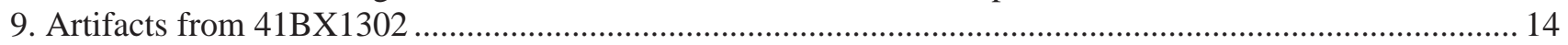

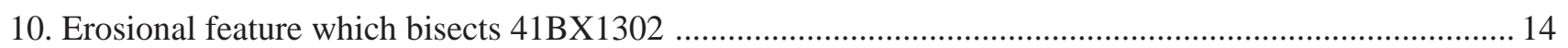

11. Artifacts observed a 1 meter below surface in south wall of erosional feature ....................................... 15

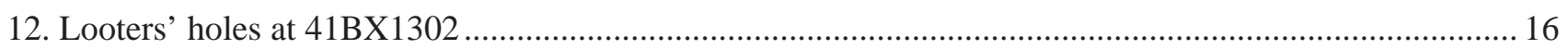

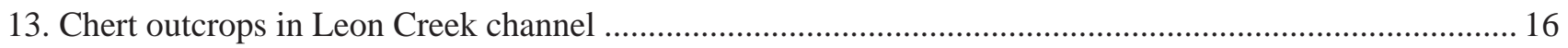

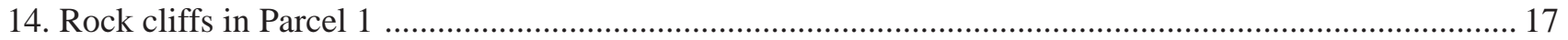

\section{Table}

1. Artifacts Collected during the Archaeological Investigation of Leon Creek 


\section{Acknowledgments}

Several people have contributed in various ways to the completion of this project. I would like to thank Paul Barwick, R. L. A., project coordinator for the Leon Creek Project, City of San Antonio Parks and Recreation Department, for his kind assistance throughout the project. Thanks also to Mr. Steve Martinez, President of the Leon Creek Greenbelt coalition (LCGC), and the dedicated members of the LCGC for their continued support and stewardship role in this project. Thanks goes to Robert J. Hard and C. Britt Bousman, director and associate director of CAR, for serving as principal investigators. Critical to any field investigation is an experienced and dedicated field crew; therefore, special thanks go to Kevin Hanselka, Bryan Langner, Preston McWhorter, Barb Meissner, Kristi Miller, Clemente Murguia, Gloria Murguia, Owen Ford, Ricky Robinson, and volunteer Eddie De La Rosa. Thanks also to Cindy Tennis, director of small projects, for her assistance and advice; and Chris Butler for drafting the figures in this report; and to Bill Bishel, our technical editor. 
This page has been

redacted because it

contains restricted

information. 


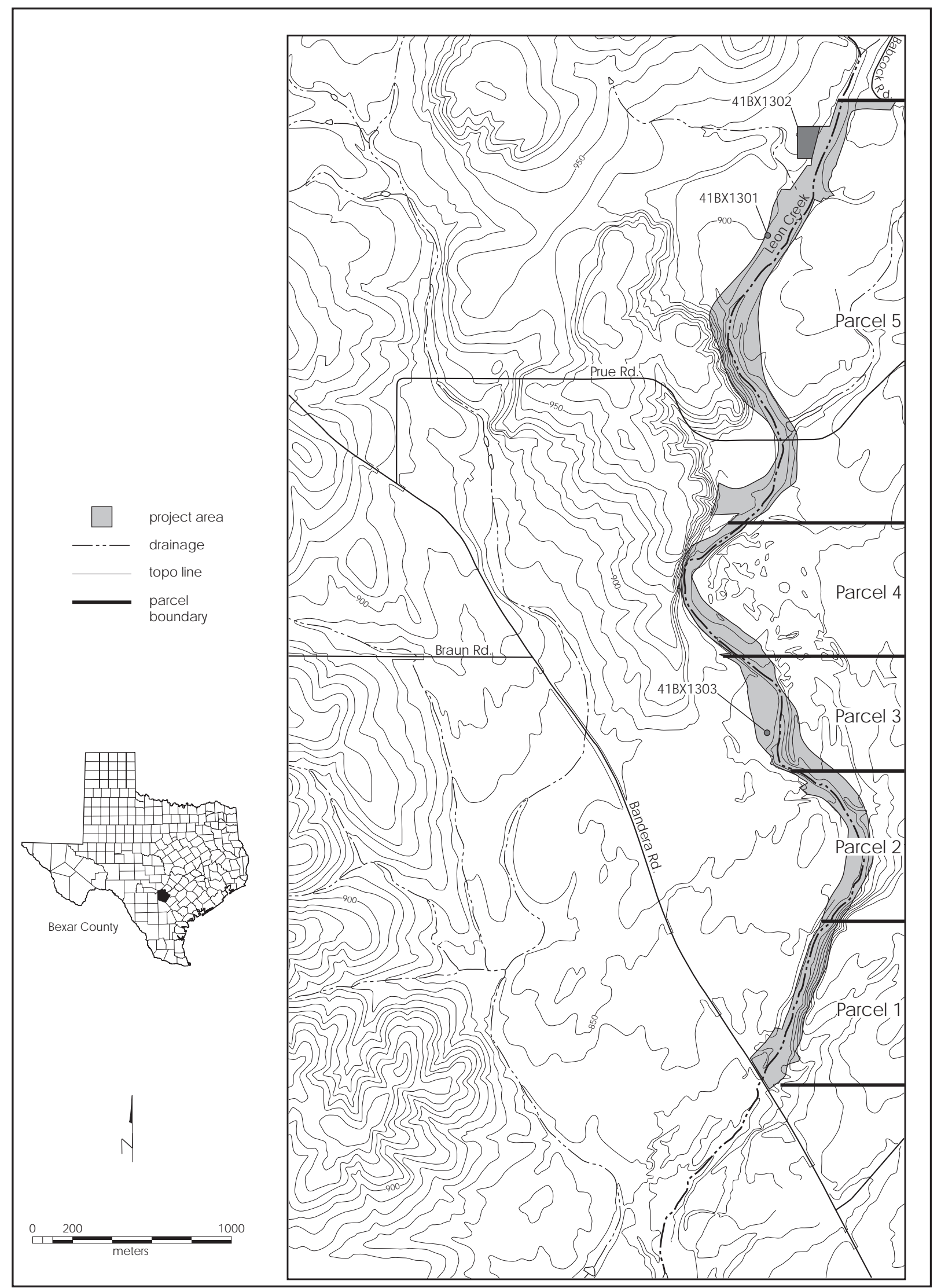

Figure 1. Location of project area. 


\section{Geology}

The geology of the project area is largely comprised of (Qt) fluviatile terrace deposits (Barnes 1983). These deposits are comprised of gravel, sand, silt, and clay. An area on the east side of Leon Creek near Bandera Road, and an area west of Leon Creek in Parcel 4 is mapped as (Kau) Austin Chalk. This deposit consists of chalk and marl with a thickness of 350-580 feet (Barnes 1983). In addition, (Kbu) Buda Limestone is present in a small area both west and east of Leon Creek in Parcel 5. Buda Limestone is poorly bedded or nodular and characteristically hard (Barnes 1983).

\section{Leon Creek}

The headwaters of Leon Creek are located in the northern part of the county in the Edwards Plateau physiographic region (Taylor et al. 1991). This part of the Edwards plateau in Bexar County ranges in elevation between 1,100 and 1,900 feet amsl. The Blackland Praire geographic region, located just south of the Edwards Plateau, has an elevational range of 700 to 1,000 feet amsl. Leon Creek traverses Bexar County from north to south where it joins the Medina River in the south-central portion of the county just south of Mitchell Lake (Corps of Engineers 1971). There is an elevational difference of approximately 1200 feet between the upper reaches of the Leon Creek watershed and the Leon Creek and Medina River confluence. The upper Leon Creek watershed is relatively wide, averaging about 11 miles in width, while the lower watershed is about 4 miles wide (Corps of Engineers 1971). Flash flooding of Leon Creek during episodes of intense rainfall is a common occurrence. While floods are usually of short duration, water levels can rise from the creek's bed to extreme flood peaks within a few hours (Corps of Engineers 1971).

\section{Cultural Chronology}

\section{Paleoindian}

The Paleoindian period in Central Texas spans approximately 3,000 years from $11,500-8,800$ B.P.
(Collins 1995). Two subperiods-Early Paleoindian $(11,500-10,000$ в.P.) and Late Paleoindian $(10,000$ 8,800 в.P.) — have been identified. Lanceolate projectile points associated with the early subperiod are Clovis, Folsom, and Plainview. Those of the late subperiod include Golondrina, Angostura, Scottsbluff, and Meserve (Black 1989a). Artifacts from the Paleoindian period are commonly found on the surface as isolated finds; however, camp, quarry/stoneworking, kill, cache, ritual, and burial sites have been reported (Collins 1995). Early Paleoindians have typically been described in the archaeological literature as nomadic, specialized "big game" hunters in pursuit of now-extinct Late Pleistocene fauna such as mammoth and Bison antiquus. With the extinction of these species, a specialized hunting strategy continued through the Late Paleoindian period but the target of prey shifted to other large herbivores such as Bison bison and deer (Odocoileus). As more data on early Paleoindian subsistence is recovered, however, the perception of "big game" hunters is giving way to "well adapted, generalized hunters-gatherers with the technology to hunt big game but not the need to rely exclusively on it" (Collins 1995:382).

\section{Archaic}

\section{Early Archaic}

The Archaic period in Central Texas spans approximately 7,500 years from $8800-1200$ or 1300 B.P. (Collins 1995). Three subperiods-Early Archaic (8800-6000 в.P.), Middle Archaic (6000-4000 в.P.) and Late Archaic (4000-1200 or 1300 B.P.) — have been identified. Changes in projectile point styles, a more localized geographic distribution of artifacts, an increase in the number of sites, and the presence of burned-rock scatters, hearths, and middens serve to separate the Archaic from the Paleoindian period (Collins 1995).

The Early Archaic period is characterized by Gower, Hoxie, Wells, Bell, Andice, Uvalde, Martindale, Baird, and Taylor (Early Triangular) projectile points (Collins and Ricklis 1994). Additional diagnostic artifacts from this subperiod include unifacial and bifacial Clear Fork 
tools, and the bifacial Guadalupe tool (Black 1989a; Collins 1995). While Early Archaic tools are found beyond Central Texas, implying "broad settlement patterns and resource utilization" (Trierweiler et al. 1995:31), a concentration of Early Archaic components located close to the eastern and southern border of the Edwards Plateau (Black 1989b; Collins 1995) along the Balcones Escarpment has been documented. One explanation for this apparent pattern targets the availability of water along the escarpment during an arid climatic interval (Black 1989b). Recovered subsistence remains demonstrate the exploitation of deer, small mammals, reptiles, amphibians, and fish. The intensified use of plant resources is indicated by the presence of cammus bulbs from earth ovens (Collins 1995). Early Archaic hunters and gatherers are considered to have been organized into small, highly mobile bands, with low population densities (Weir 1976).

\section{Middle Archaic}

The Middle Archaic is characterized by Nolan, Travis, Bulverde, Pedernales, Marshall, Williams, and Lange stemmed projectile points (Collins and Ricklis 1994). In comparison to the Early Archaic, the Middle Archaic is represented by an increase in the number of sites, site size, and number of diagnostic artifact types (Collins and Ricklis 1994). Weir (1976) proposes that the observed increase in site density during this period was a direct result of increased population density.

Burned-rock features including scatters, hearths, and middens are hallmarks of the Middle Archaic period in Central Texas (Collins 1995). The number of burned-rock middens increases, and the maximum size and thickness of these features are reached during this period (Collins and Ricklis 1994). Several ideas regarding the function of burned-rock middens have been offered; however, it is commonly accepted that their presence is directly linked to food processing. Subsistence remains recovered from burned-rock middens include deer, acorns, and charred bulbs.

\section{Late Archaic}

The Late Archaic is characterized by Marcos, Castroville, Montell, Ensor, Frio, Fairland, and Darl points (Collins and Ricklis 1994). The number of sites and components reaches an all-time high in the Late Archaic period of Central Texas prehistory (Trierweiler et al. 1995). If site density is an accurate indicator of population density, it appears that the prehistoric population of Central Texas peaked at this time (Trierweiler et al.1995). For the first time in the prehistory of Central Texas, cemetery sites became part of the archaeological inventory of site types. Relatively large trade networks are indicated by the presence of marine shell in cemeteries, and corner tang knives have been recovered throughout Texas and beyond (Trierweiler et al.1995). As for burned rock, "accumulating evidence supports continued and possibly increased use, throughout the Late Archaic" (Trierweiler et al. 1995:33).

\section{Late Prehistoric Period}

The Late Prehistoric period in Central Texas spans approximately 800 years from 1150-350 в.P. (Black 1989a). Two phases identified within this period are the Austin phase (1150-650 в.P.) and the Toyah phase (A.D. $650-350$ B.P.). The Late Prehistoric period is characterized by changes in point style and ceramic manufacture (Trierweiler et al.1995). The presence of small arrow points (Edwards, Scallorn, and Perdiz) indicates a change to bow-and-arrow technology (Collins 1995).

The Austin phase is considered to be a continuation of the Late Archaic adaptation with an equal emphasis on both hunting and gathering (Collins and Ricklis 1994). Similarly, cemeteries containing marine shell artifacts remain in use during this time.

Based on the presence of bison remains and a tool assemblage comprised of Perdiz arrow points, large unifacial end scrapers, and beveled bifacial knives, Toyah phase sites reflect a shift in the exploitation of resources (Collins and Ricklis 1994). This tool assemblage is believed to be associated with the hunting and processing of bison. However, Toyah phase com- 
This page has been

redacted because it

contains restricted

information. 


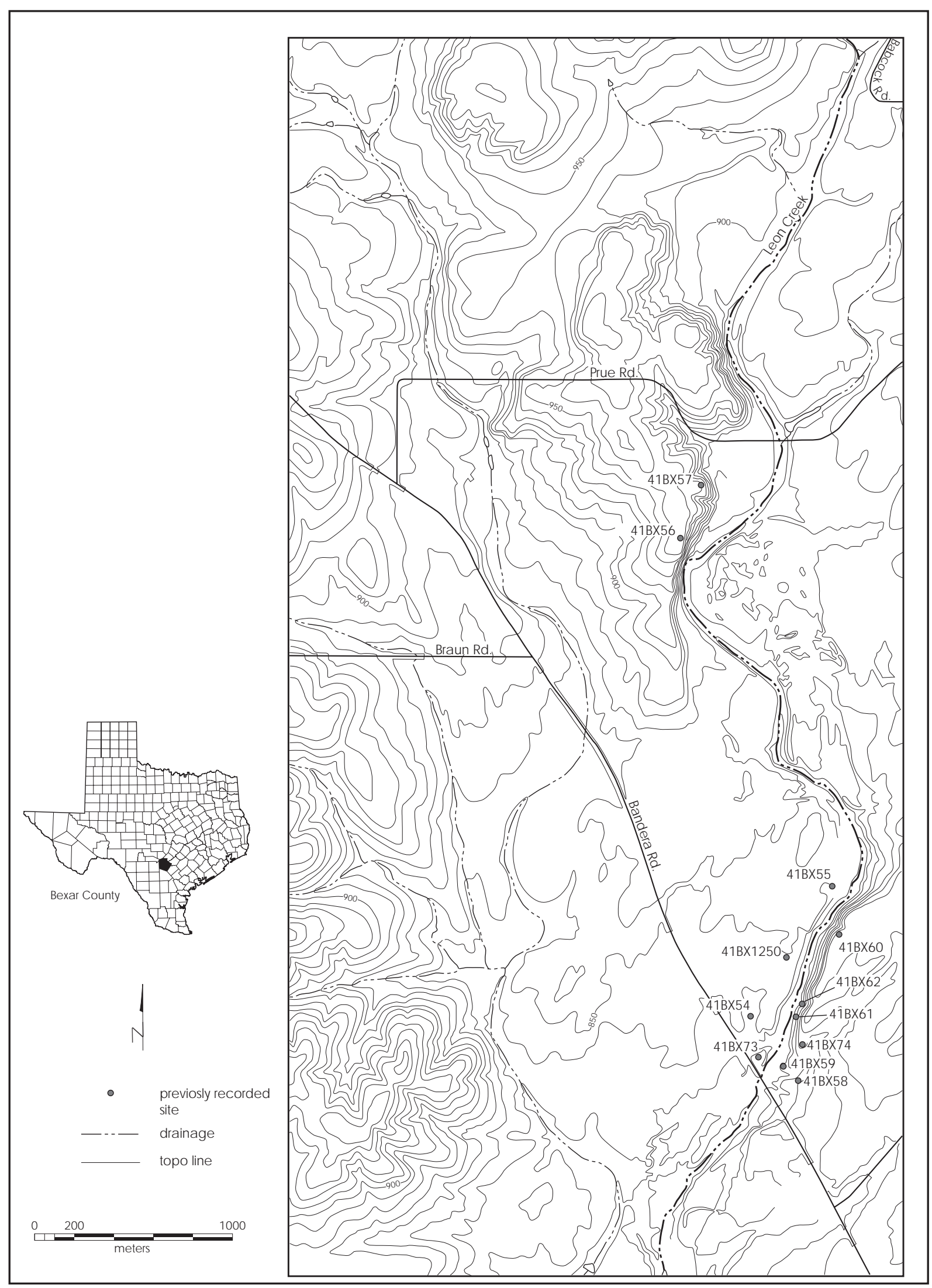

Figure 2. Previously recorded sites in and near the project area. 
eroded area, and appears to be in poor condition having been excavated or eroded away. All visible lithic artifacts were collected and a sample of burned rock was recovered. Due to the poor condition of the site, no further work was recommended.

In 1971, Paul McGuff and Bill Fawcett recorded site 41BX61 (site form on file at TARL). This site is reported to be located on the wall of a bluff east of Leon Creek (Figure 2). It is described as both a rockshelter and cave. A small still, perhaps from the Prohibition period, was observed at the mouth of the rockshelter. Apparently a rockfall has closed off most of the opening into the rockshelter, and has crushed the still as well. A search was made inside the rockshelter and cave, but no cultural material was observed. This rockshelter was reported by McGuff and Fawcett to be the only one which contained a deep fill of limestone dust.

Site 41BX62 was recorded in 1971 by Bill Fawcett and Paul McGuff (site form on file at TARL). The site is located on the east side of Leon Creek and is described as a large rockshelter in the wall of a bluff (Figure 2). This rockshelter is reported to be approximately 50 feet above Leon Creek. Cultural material consisted of several flakes which were collected from the talus slope. No further work was recommended.

In 1997, Weir Enterprises conducted a pedestrian survey and backhoe trenching of a location targeted for the construction of the Bandera Commons Apartments west of Leon Creek (Weir 1997). Site 41BX54, originally recorded by McGuff in 1971 (see below) was reestablished; and a new site, 41BX1250 was newly documented (Figure 2). Site 41BX1250 is described as being less than 50 meters in diameter and consisting of a light scatter of burned rock, two core fragments, and three flint flakes (Weir 1997). The cultural material from 41BX1250 appears to be restricted to the top $60 \mathrm{~cm}$ of soil. Weir concluded that due to extensive disturbance in the project area (e.g. leveling and agricultural activities, construction of radio station and four radio towers, soil mining, etc.) sites 41BX54 and 41BX1250 not be recommended as eligible for listing in the National Register of Historic Places.

Site 41BX60 was recorded by Paul and Ellen McGuff in 1971 (site form on file at TARL). The site is located on a high bluff on the east side of Leon Creek (Figure 2). It is described as a small, open campsite; perhaps representing only a single night's occupation. All visible lithic artifacts were recovered including a Montell and an Almagre point. A few pieces of burned rock were also observed but only a single sample was collected.

In 1971, Paul McGuff recorded site 41BX55 (site form on file at TARL). This site is located on the west side of Leon Creek and was observed in the western wall of a gravel pit (Figure 2). The majority of the site may have been removed during gravel quarrying. Cultural material was only observed below the present surface in the wall of the pit. The depth at which this material was observed is not reported. The site was not recommended for further testing.

In 1971, Paul McGuff and Bill Fawcett recorded site 41BX56 (site form on file at TARL). The site is located on top of a 100-foot bluff west of Leon Creek (Figure 2). It is reported to be a large open air campsite from possibly the Paleoindian and Archaic periods. Artifacts collected include an Angostura, Bulverde, and Nolan point, as well as several bifaces, unifaces, and numerous flakes.

Site 41BX57 was recorded by Paul and Ellen McGuff in 1971 (site form on file at TARL). This site is located on a high bluff on the west side of Leon Creek (Figure 2). The McGuff's described this site as a hunting camp from the Early Archaic or Late PaleoindianArchaic periods. All visible artifacts were reported to have been collected including one lanceolate point and several bifaces. A Bulverde and a Castroville point were also observed; however, it is unclear whether these two dart points were collected.

\section{Methodology}

Pedestrian survey and shovel testing were conducted in two separate phases, Phase I and Phase IA. Phase I included pedestrian survey of Parcels 1, 2, 4, and 5, and shovel testing Parcels 2, 3, 4, and 5. Phase IA consisted of pedestrian survey and shovel testing Parcel 3. (Parcel 1 did not contain enough high probability areas to be shovel tested.) 
The entire project area was pedestrian surveyed at 30 meter intervals. Cutbanks and erosional profiles were inspected for the presence of subsurface cultural deposits. With the exception of exposed limestone directly in the Leon Creek channel, ground cover was dense across the project area and the percentage of ground surface visible ranged between 0 and 30 percent. Since the majority of the project area is in the floodplain, shovel tests were dug only in select areas (i.e. T1 terraces) where the chance of encountering significant cultural resources was considered high.

Eighty-two shovel tests were dug in the project area. They are located in the following Parcels: STs 1-18, 58-61, and 80-82 in Parcel 2 (Figure 3), STs 67-79 in Parcel 3 (Figure 4), STs 55-57 in Parcel 4 (Figure 5), and STs 19-54 and 62-66 in Parcel 5 (Figure 6). Shovel tests were spaced at 50-meter intervals except those excavated to determine the horizontal and vertical extent of archaeological sites. Shovel tests were approximately $30 \mathrm{~cm}$ in diameter and dug in $10 \mathrm{~cm}$ levels to a maximum depth of $50 \mathrm{~cm}$ below surface. All soil was screened through 1/4-inch wire mesh and all artifacts were collected. Standard CAR shovel test forms were completed for each individual shovel test. Photographs were taken with a Fuji 35-mm camera using color print film. All cultural material was taken to the CAR laboratory for analysis and curation (see Laboratory Methods).

\section{Laboratory Methods}

Cultural material was brought to the CAR laboratory facility and washed, air-dried, labeled, catalogued, and analyzed. All artifacts, field forms, notes, records, and photographs were curated in archival quality (acidfree) containers, labeled, inventoried, and placed in CAR's permanent shelving.

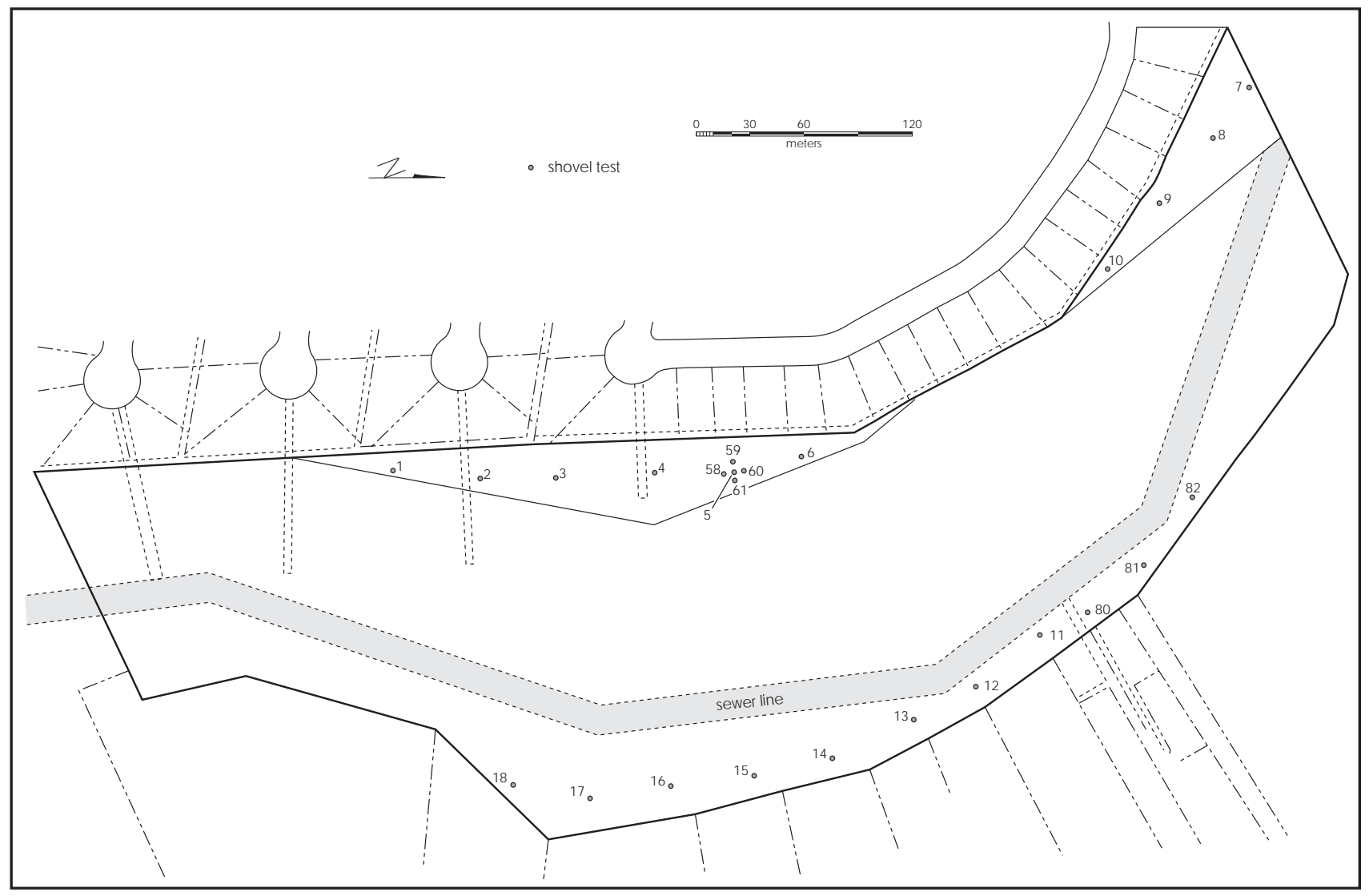

Figure 3. Locations of shovel tests in Parcel 2. 


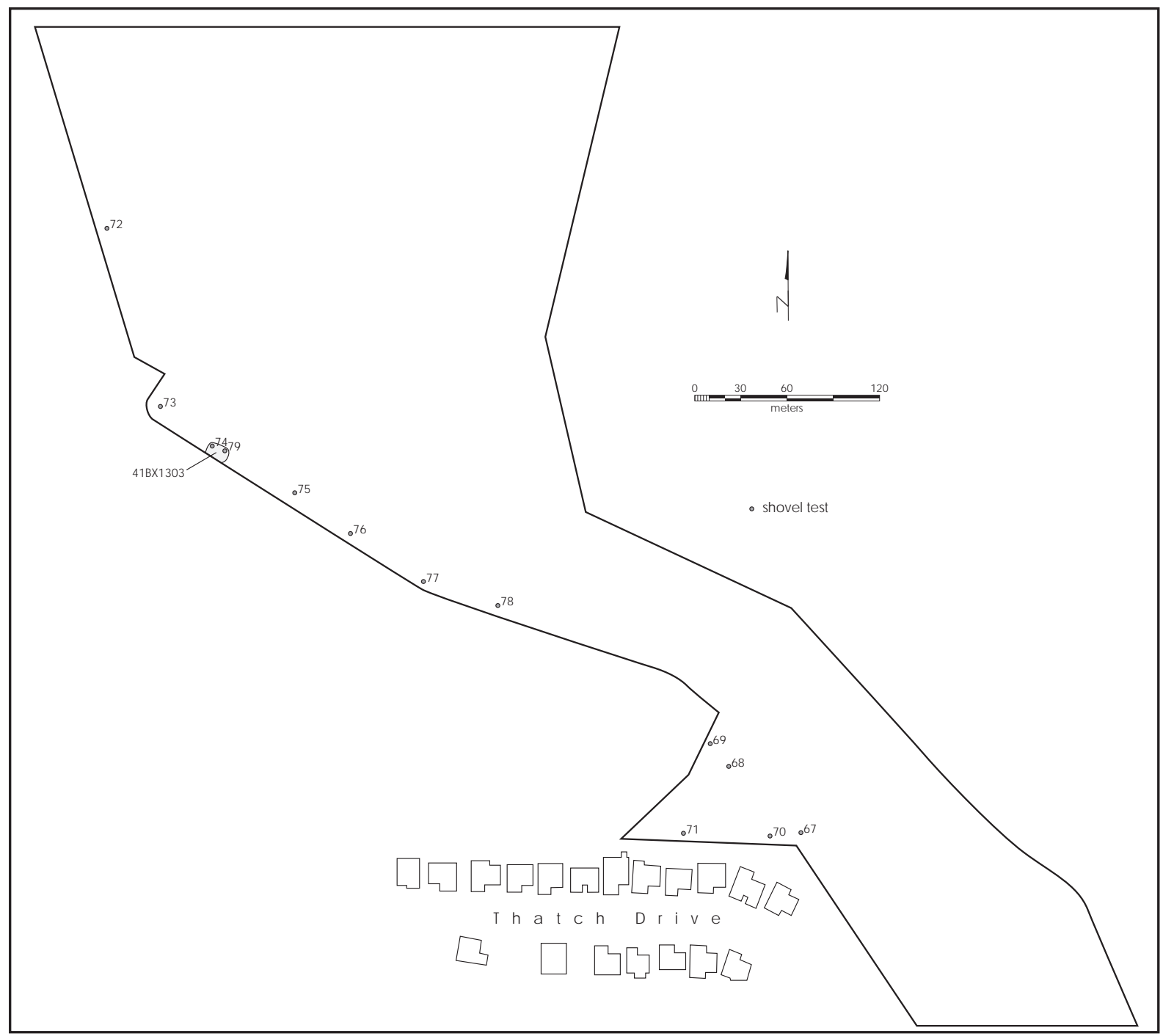

Figure 4. Locations of shovel test in Parcel 3 and site 41BX1303.

\section{Artifact Analysis}

Lithic artifacts were analyzed by class, raw material, and attributes. The artifacts were analyzed by the project archaeologist under the supervision and advice of Steve A. Tomka. From the debitage category, only complete flakes - those having both a platform and termination-were analyzed.

\section{Results}

Three newly identified archaeological sites were documented during the current investigation. Site 41BX1301 is located on the slope of a T1 terrace on the west side of Leon Creek in Parcel 5 (Figures 1 and
6). Artifacts from this site were not collected; however, an examination of the cultural material indicates that 41BX1301 is comprised of a light density of primary, secondary, and tertiary flakes, and cores. Some of the material, especially the larger cores, show many internal flaws. Given the location of 41BX1301 on the slope of a T1 terrace, it is assumed that the majority of the site is located on the T1 terrace west of the project area, and the artifacts observed are in a secondary context as a result of colluvial processes. The $\mathrm{T} 1$ terrace west of the site has been developed; a hikeand-bike trail and housing subdivision are present. The site is approximately 120 meters in length. The slope of the T1 terrace within the project area is approximately 10 meters in width and the base of the slope leads directly into the exposed limestone bedrock of 


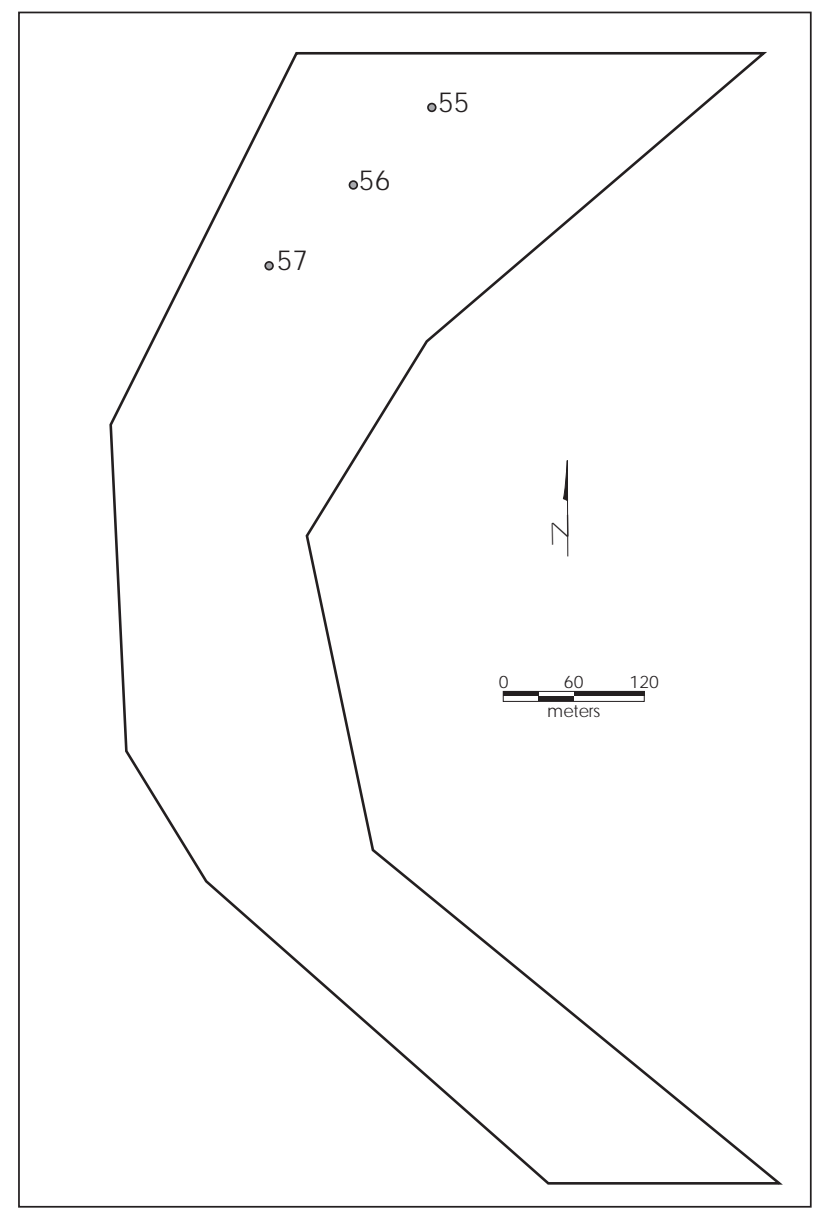

Figure 5. Locations of shovel tests in Parcel 4.

the Leon Creek Channel (Figure 7). With the exception of one complete unifacial flake recovered from level $1(0-10 \mathrm{~cm})$ of ST 44 (Table 1 and Appendix A), no other cultural material was observed in the three shovel tests (STs 42, 43, and 44) excavated within the site boundaries.
Site 41BX1302 is located on a T1 terrace on the west side of Leon Creek in Parcel 5 (Figures 1, 6, and 8). The site appears to be comprised of at least two prehistoric components; an upper deposit and a buried component. Site 41BX1302 was first recognized during pedestrian survey by the presence of tertiary flakes and a few fragments of burned rock on the ground surface. Ground cover on this terrace is dense; however, limited areas afforded adequate surface visibility. Six shovel tests were excavated to determine the horizontal and vertical extent of cultural material. Fifty-seven artifacts were collected from 41BX1302 (Table 1 and Appendix A). Artifacts are concentrated in the upper two levels; however, STs 53 and 66 yielded one broken tertiary flake and one thin biface fragment, respectively, in level $4(30-40 \mathrm{~cm})$; and STs 64 and 65 each contained one flake in level 5 (40-50 $\mathrm{cm})$. The proximal section of a Marcos dart point was collected from the surface approximately 25 meters northeast of ST 53 (Figures 8 and 9; Appendix A ). In addition, a distal fragment of a projectile point was recovered in a dirt road which runs along the northern boundary of the site (Figure 8 and Appendix A). The site is approximately 135 meters north/south by 75 meters east/west. Cultural material is also eroding off the terrace into the creek. It is highly probable that the site extends west (if not totally destroyed by the construction of a housing subdivision), and north and south of the project boundary.

A visual inspection was conducted on both walls of a northwest/southeast erosional cut which bisects the site (Figures 8 and 10). This erosional feature is the result of an artificial cut created to provide drainage to a housing development located adjacent and west

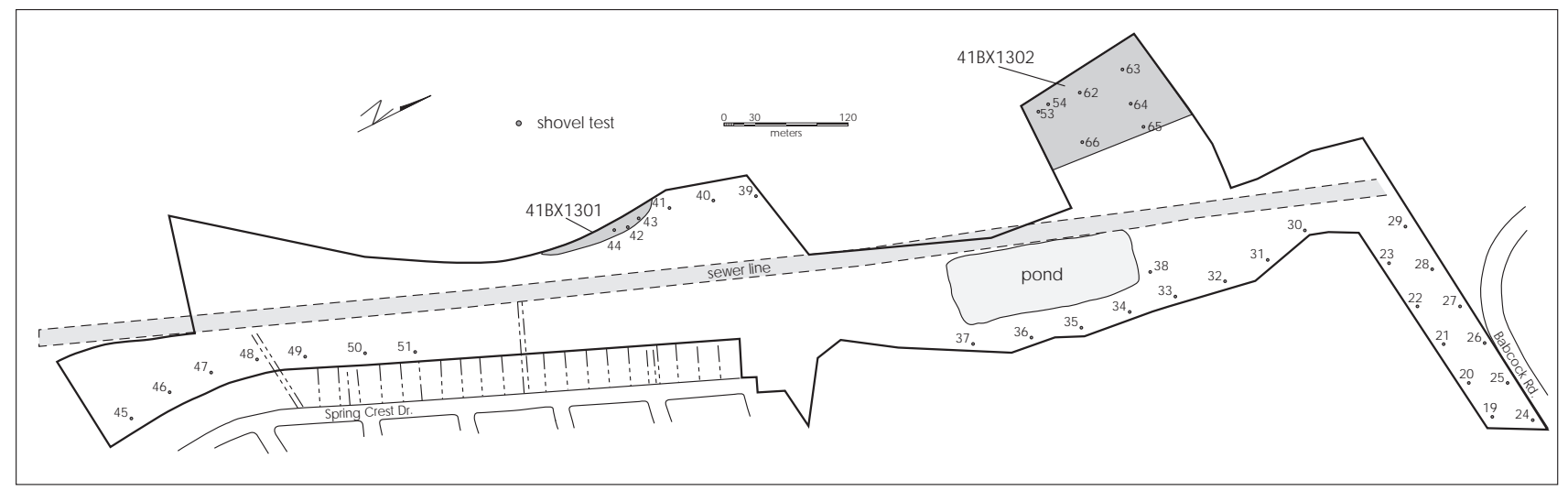

Figure 6. Locations of shovel tests in Parcel 5 and sites $41 B X 1301$ and $41 B X 1302$. 


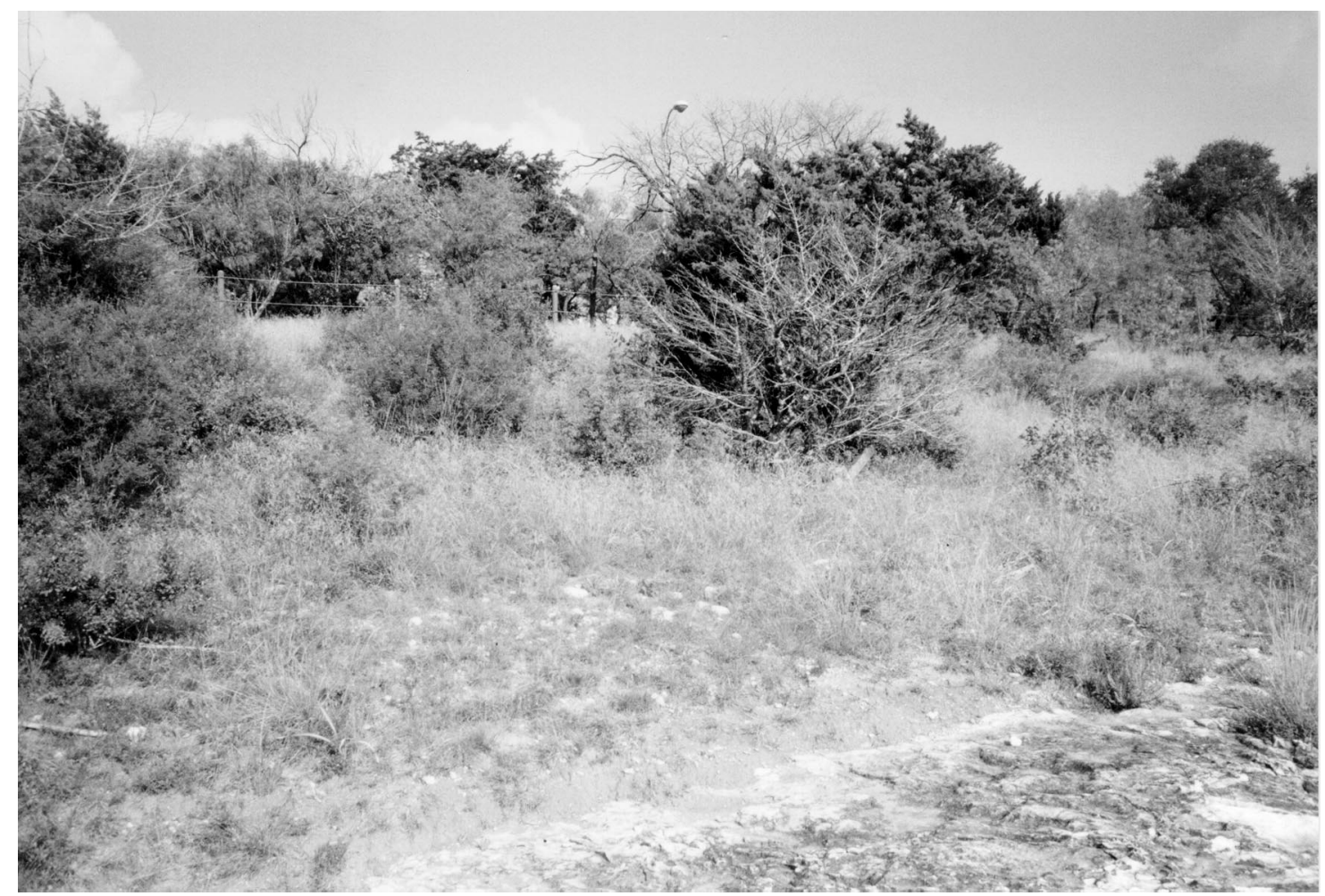

Figure 7. Site 41BX1301.

of the site. A buried component, located approximately 25-30 meters east of the eastern project boundary, was documented (Figure 8). The artifacts observed in the north and south wall profiles are concentrated in a 10-20 cm thick lens approximately one meter below the surface (Figure 11). This cultural lens has a horizontal distribution of approximately 10 meters. The material observed within the profile is characterized as light in density, and the artifacts include three bone fragments, 11 tertiary flakes, one secondary flake, one primary flake, charcoal, and possibly burned-rock fragments. Two bone fragments recovered from the profile have been identified as artiodactyl, probably deer. The cultural lens is present in a black (10YR 2.5/1) sandy clay loam containing approximately 30 percent gravels which range in size from $2-5 \mathrm{~cm}$ in diameter. Rabdotus snail shell was observed in direct association with the cultural lens. Directly underlying the artifacts is a dense concentration of alluvial gravels (approximately 95 percent) which range between 2 and $10 \mathrm{~cm}$ in diameter. In addition to the subsurface lens, artifacts were noted on the ground surface near the erosional cut; interestingly, however, no cultural material appears to be present in the profile between the surface and the 1-meter deep deposit, although nearby shovel tests contained artifacts to a depth of $50 \mathrm{~cm}$ below surface. Several artifacts were observed in the bottom of the erosional feature which empties into the Leon Creek channel to the east. These include 4 bifaces, three primary, five secondary, and thirteen tertiary flakes, and one core fragment. One dart point, identified as an Ensor (Steve Tomka, personal communication) was recovered in a secondary context near the confluence of the erosional cut and the creek channel (Figures 8 and 9; Appendix A). It is not known whether the Ensor point may have eroded from this buried deposit, if it originated in the upper deposit, or if it was transported by Leon Creek from some unknown location.

While mapping the site with a Global Positioning System (GPS), three looters' holes were observed near its northeastern boundary (Figure 8). While each looters' hole (approximately 1.5 meters in diameter) can be identified individually, in actuality they comprise one large pit due to their close proximity to one another (Figure 12). Artifacts observed within the backdirt include flakes, burned rock, and two late-stage biface fragments. The only artifacts collected from the backdirt pile were the two biface fragments. The burned rock is of light to 
Table 1. Artifacts Collected during the Archaeological Investigation of Leon Creek

\begin{tabular}{|c|c|c|c|c|c|c|}
\hline Provenience & $\begin{array}{l}\text { Ground } \\
\text { Surface } \\
\end{array}$ & $\begin{array}{c}\text { Level 1 } \\
(0-10 \mathrm{~cm}) \\
\end{array}$ & $\begin{array}{c}\text { Level } 2 \\
(10-20 \mathrm{~cm}) \\
\end{array}$ & $\begin{array}{c}\text { Level } 3 \\
(20-30 \mathrm{~cm}) \\
\end{array}$ & $\begin{array}{c}\text { Level } 4 \\
(30-40 \mathrm{~cm}) \\
\end{array}$ & $\begin{array}{c}\text { Level } 5 \\
(40-50 \mathrm{~cm}) \\
\end{array}$ \\
\hline Shovel Test 5 & & & & & $\begin{array}{l}\text { incomplete } \\
\text { tertiary flake }\end{array}$ & \\
\hline Shovel Test 30 & & & $\begin{array}{l}\text { incomplete } \\
\text { tertiary flake }\end{array}$ & & & \\
\hline \multicolumn{7}{|c|}{ Site 41BX301-Parcel 5} \\
\hline Shovel Test 44 & & $\begin{array}{l}\text { complete } \\
\text { tertiary flake }\end{array}$ & & & & \\
\hline \multicolumn{7}{|c|}{ Site 41BX302-Parcel 5} \\
\hline Shovel Test 53 & & \begin{tabular}{|l|}
7 incomplete \\
tertiary flakes \\
and 1 complete \\
indeterminate \\
flake \\
\end{tabular} & $\begin{array}{l}3 \text { incomplete } \\
\text { tertiary flakes }\end{array}$ & & $\begin{array}{l}1 \text { incomplete } \\
\text { tertiary flake }\end{array}$ & \\
\hline Shovel Test 62 & & $\begin{array}{l}6 \text { incomplete } \\
\text { flakes (one } \\
\text { primary and } 5 \\
\text { tertiary) and } 1 \\
\text { complete } \\
\text { platform/core } \\
\text { flake }\end{array}$ & & & & \\
\hline Shovel Test 63 & $\begin{array}{l}1 \text { incomplete } \\
\text { tertiary flake }\end{array}$ & $\begin{array}{l}6 \text { incomplete } \\
\text { tertiary flakes }\end{array}$ & $\begin{array}{l}3 \text { incomplete } \\
\text { tertiary flakes } \\
\text { and } 1 \text { corticate } \\
\text { chip }\end{array}$ & $\begin{array}{l}5 \text { incomplete } \\
\text { tertiary flakes }\end{array}$ & & \\
\hline Shovel Test 64 & & \begin{tabular}{|l|}
5 incomplete \\
tertiary flakes, 1 \\
chert chip, and 1 \\
incomplete \\
utilized flake
\end{tabular} & $\begin{array}{l}3 \text { incomplete } \\
\text { tertiary flakes } \\
\text { and } 1 \text { complete } \\
\text { biface thinning } \\
\text { flake }\end{array}$ & $\begin{array}{l}1 \text { incomplete } \\
\text { tertiary flake } \\
\text { and } 1 \text { complete } \\
\text { platform/core } \\
\text { preparation } \\
\text { flake }\end{array}$ & & $\begin{array}{l}1 \text { incomplete } \\
\text { tertiary flake }\end{array}$ \\
\hline Shovel Test 65 & & & $\begin{array}{l}3 \text { incomplete } \\
\text { tertiary flakes }\end{array}$ & $\begin{array}{l}1 \text { incomplete } \\
\text { tertiary flake }\end{array}$ & & $\begin{array}{l}1 \text { incomplete } \\
\text { tertiary flake }\end{array}$ \\
\hline Shovel Test 66 & & & 1 chert chip & & $\begin{array}{l}1 \text { late-stage } \\
\text { biface medial } \\
\text { fragment }\end{array}$ & \\
\hline $\begin{array}{l}\text { Confluence of } \\
\text { erosional feature and } \\
\text { Leon Creek }\end{array}$ & $\begin{array}{l}\text { Ensor Projectile } \\
\text { Point }\end{array}$ & & & & & \\
\hline $\begin{array}{l}25 \mathrm{~m} \text { northeast of ST } \\
53\end{array}$ & $\begin{array}{l}\text { Proximal } \\
\text { section of a } \\
\text { Marcos dart } \\
\text { point }\end{array}$ & & & & & \\
\hline $\begin{array}{l}\text { Backdirt from Looter's } \\
\text { Holes }\end{array}$ & \begin{tabular}{|l|}
2 late-stage \\
biface fragments
\end{tabular} & & & & & \\
\hline $\begin{array}{l}\text { Dirt Road along } \\
\text { northern boundary }\end{array}$ & $\begin{array}{l}\text { Distal section of } \\
\text { projectile point }\end{array}$ & & & & & \\
\hline \multicolumn{7}{|c|}{ Site 41BX303-Parcel 3} \\
\hline Vehicle Tracks & \begin{tabular}{|l|}
6 incomplete \\
flakes (2 \\
secondary and 4 \\
tertiary) and 2 \\
chert chips \\
\end{tabular} & & & & & \\
\hline
\end{tabular}




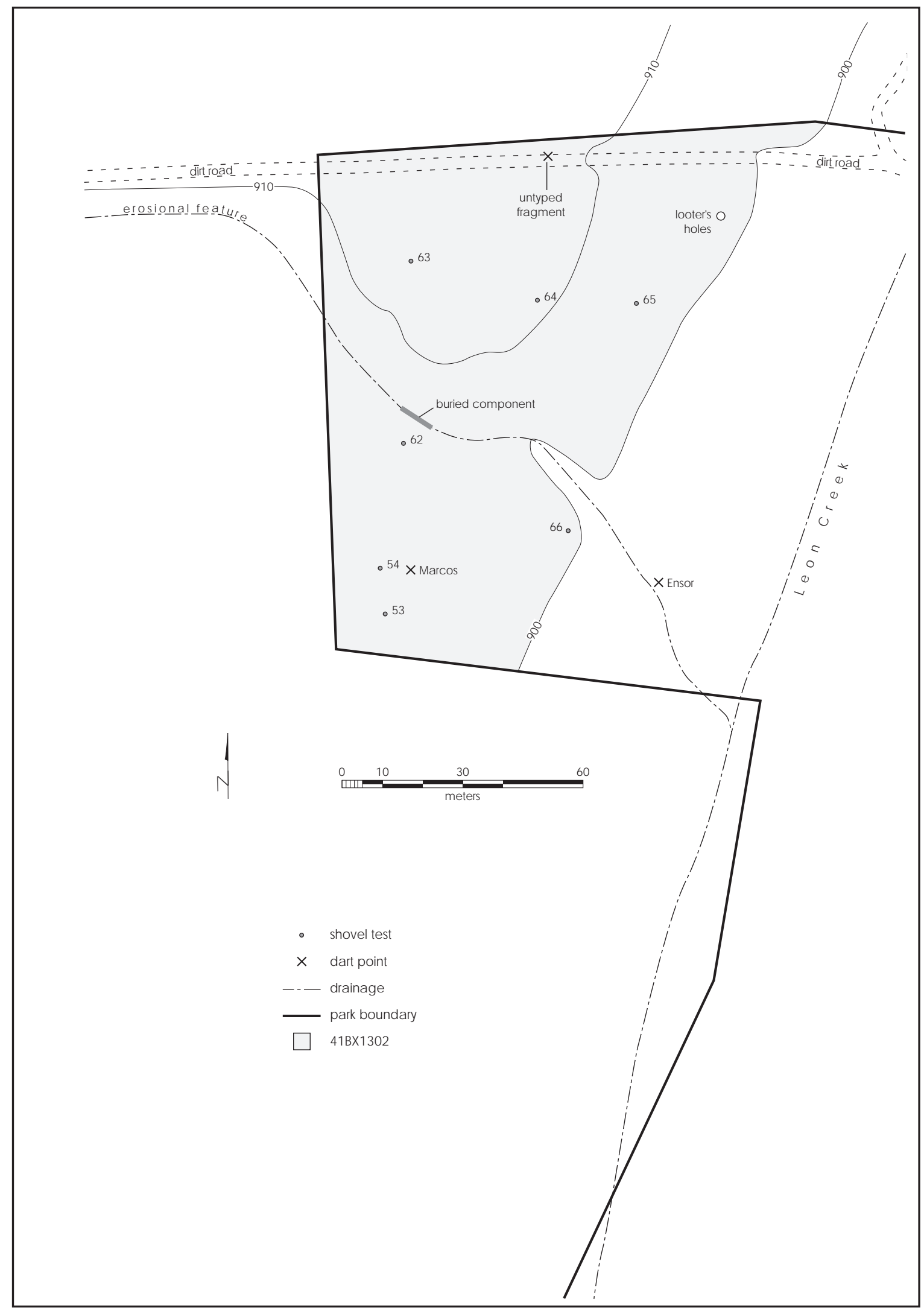

Figure 8. Site 41BX1302 showing shovel tests, erosional feature, buried component, and looters', hole. 


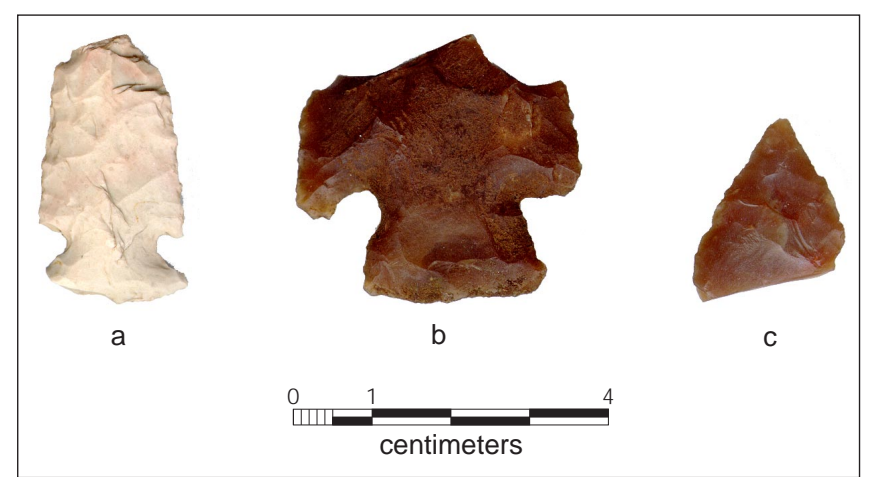

Figure 9. Artifacts from 41BX1302. a. Ensor; b. Marcos; c. distal section.

medium density and does not appear to represent a dense midden (i.e. earthen oven).

Cultural material recovered from 41BX1302 provides but a small sample of the site's lithic material; however, analysis of the artifact assemblage suggests that initial lithic reduction was not a common occurrence at this site. Of 55 pieces of debitage, 48 are small tertiary flakes. If lithic manufacture included early stage reduction, one would expect to see more primary and secondary flakes. Only four flakes from 41BX1302 were identified as complete and therefore analyzed; they include one biface thinning flake, two platform/core preparation flakes, and one indeterminate. In addition to the recovery of the proximal section of a Marcos

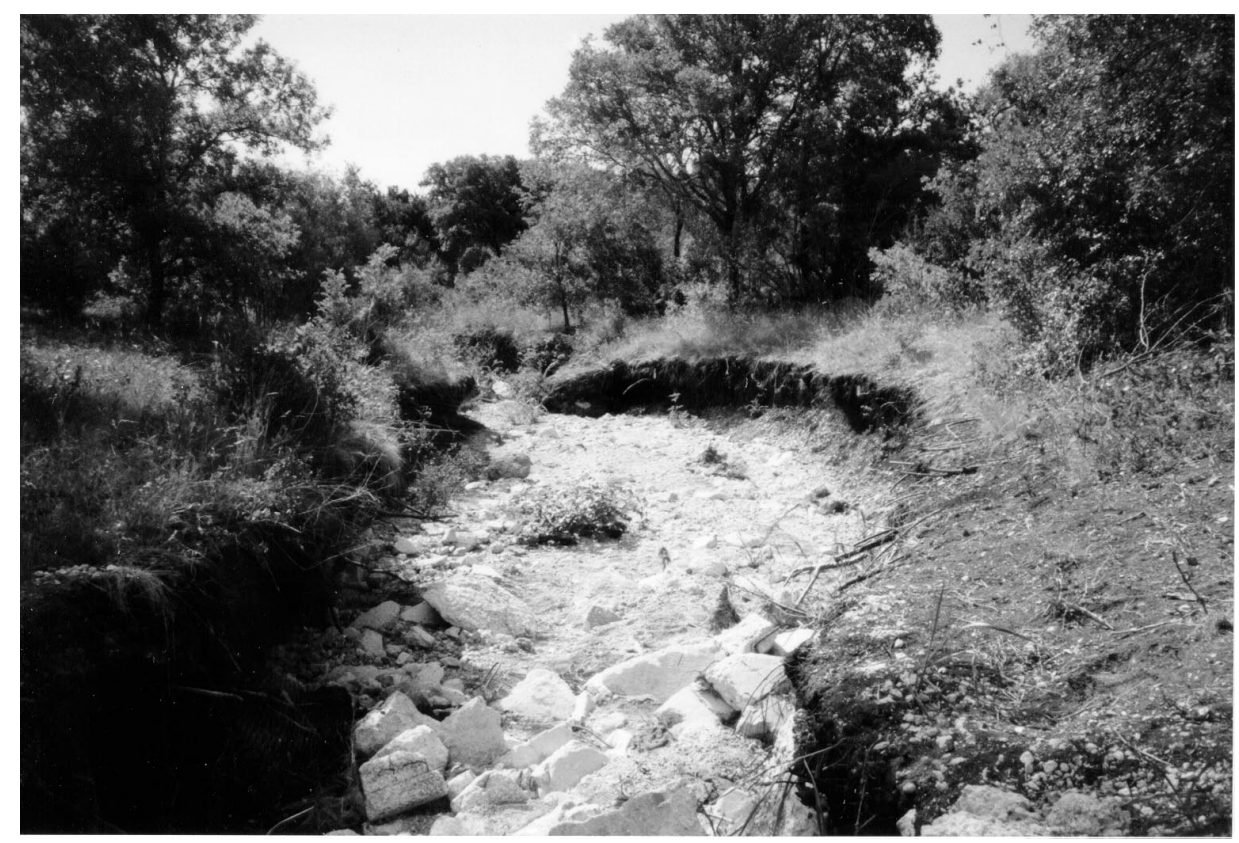

Figure 10. Erosional feature which bisects 41BX1302. dart point from the site, the distal section of a projectile point and three late-stage biface fragments were collected. The break type of the Marcos dart point is indicative of a break resulting from use, and the distal section of the projectile point exhibits a manufacturing break. The Ensor point found in a secondary context near 41BX1302 exhibited a break type resulting from use and/or resharpening. The break type of two of the three late-stage biface fragments are identified as indeterminate and the third exhibits a break type indicative of manufacture. The attributes of the artifacts and the lithic assemblage as a whole suggests that lithic material in the form of middle- stage bifaces and/ or secondary macro-flakes were being brought to the site and further reduced and/or finished. During the pedestrian survey of the project area, chert outcrops were observed eroding from Edward's Limestone in the Leon Creek channel near this site (Figure 13). It is possible that this source of raw material was utilized by the prehistoric inhabitants at 41BX1302.

A third site, 41BX1303, is located near the base of a slope of a T1 terrace on the west side of Leon Creek in Parcel 3 (Figures 1 and 4). Lithic artifacts were observed in vehicle tracks where visibility was adequate due to the absence of tall grass. A limited inspection of the tracks north of the project area showed that artifacts were present on the mid-slope of the $\mathrm{T} 1$ terrace as well. With the exception of the toeslope, the T1 terrace is located on private property. The artifacts observed within the project area are considered to be in a secondary context having originated from the $\mathrm{T} 1$ terrace on private property. Two shovel tests (STs 74 and 79) were excavated near the observed artifacts and both shovel tests showed negative results for subsurface material. Artifacts observed within the site include secondary and tertiary flakes. The proximal section of a Pedernales dart point was observed outside the project area on the mid-slope of the $\mathrm{T} 1$ terrace. 


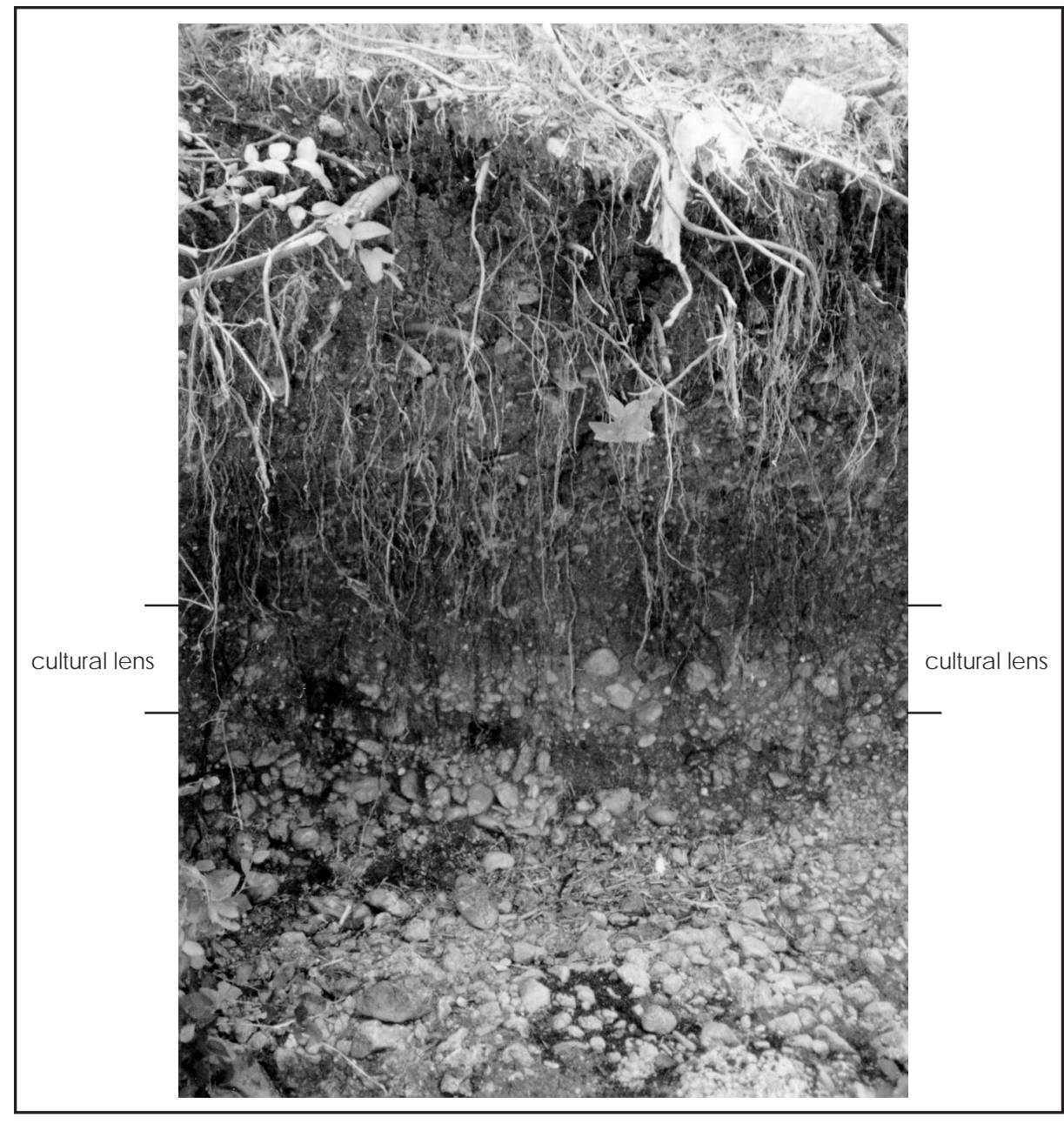

Figure 11. Artifacts observed at 1 meter below surface in south wall of erosional feature.

\section{Artifacts}

Seventy-two lithic artifacts (56 incomplete flakes, 5 complete flakes, 5 chert chips, 3 late-stage biface fragments, an Ensor dart point, a Marcos dart point, and the distal section of a projectile point) were collected during the course of this project (Table 1). With the exception of three artifacts collected from the ground surface and two recovered from the backdirt pile of a looters hole at 41BX1302, and six from the ground surface at 41BX1303, the remaining cultural material was recovered during the excavation of shovel tests. Of the 82 shovel tests excavated in the project area, STs 5 and 30 are the only ones located outside newly identified archaeological sites which contain cultural material. A single tertiary flake was recovered from each shovel test; however, modern materials were also present indicating a high degree of disturbance from the construction of adjacent housing developments. Four additional shovel tests were excavated five meters from ST 5 , one in each of the cardinal directions. These four shovel tests did not yield prehistoric materials, only additional modern construction material. Additional shovel tests were not excavated around ST 30 due to the narrow width of the terrace present in the project area and to the close proximity of a privacy fence and housing division.

Four of the archaeological sites recorded by McGuff in 1971 fall within the project boundary; however, the current investigation was unable to relocate and redocument these sites. Understandably, site $41 \mathrm{BX} 73$ was not relocated as it represents a burial which had been previously removed; however, no cultural material nor features associated with sites 41BX59, 41BX61, and 41BX62 were observed. Site 41BX59 is reported to be located in the active floodplain at or near the eastern project boundary. Burned rock and lithics were said to have formed a mound or were on a mound. All cultural material (presumably lithics) was collected in 1971, and the site was reported to be covered in thick brush. It may be that flooding and erosion have destroyed the site, or that the site is located adjacent and immediately east of the project boundary. Sites 41BX61 and 41BX62 are reported to be located on the eastern side of Leon Creek (Figure 2). 41BX61 is described as a rockshelter and a cave; however, with the exception of a small still (possibly from the Prohibition period) located near the mouth of the rockshelter, no other cultural material was observed in 1971. Site 41BX62 is described as a rockshelter in the wall of a bluff 50 feet above Leon Creek. Cultural material was not observed within the rock shelter in 1971 but several lithic flakes were 


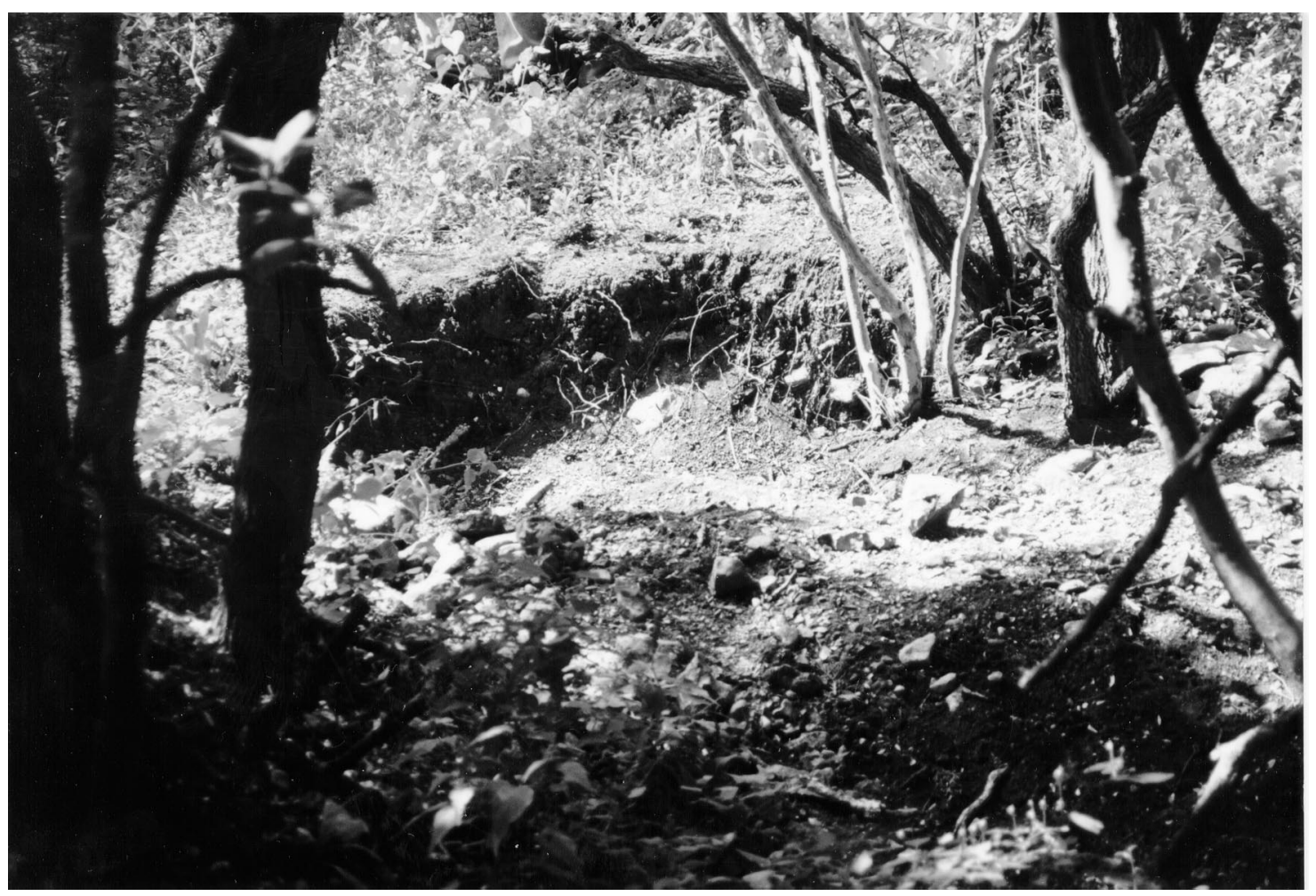

Figure 12. Looters' holes at 41BX1302.

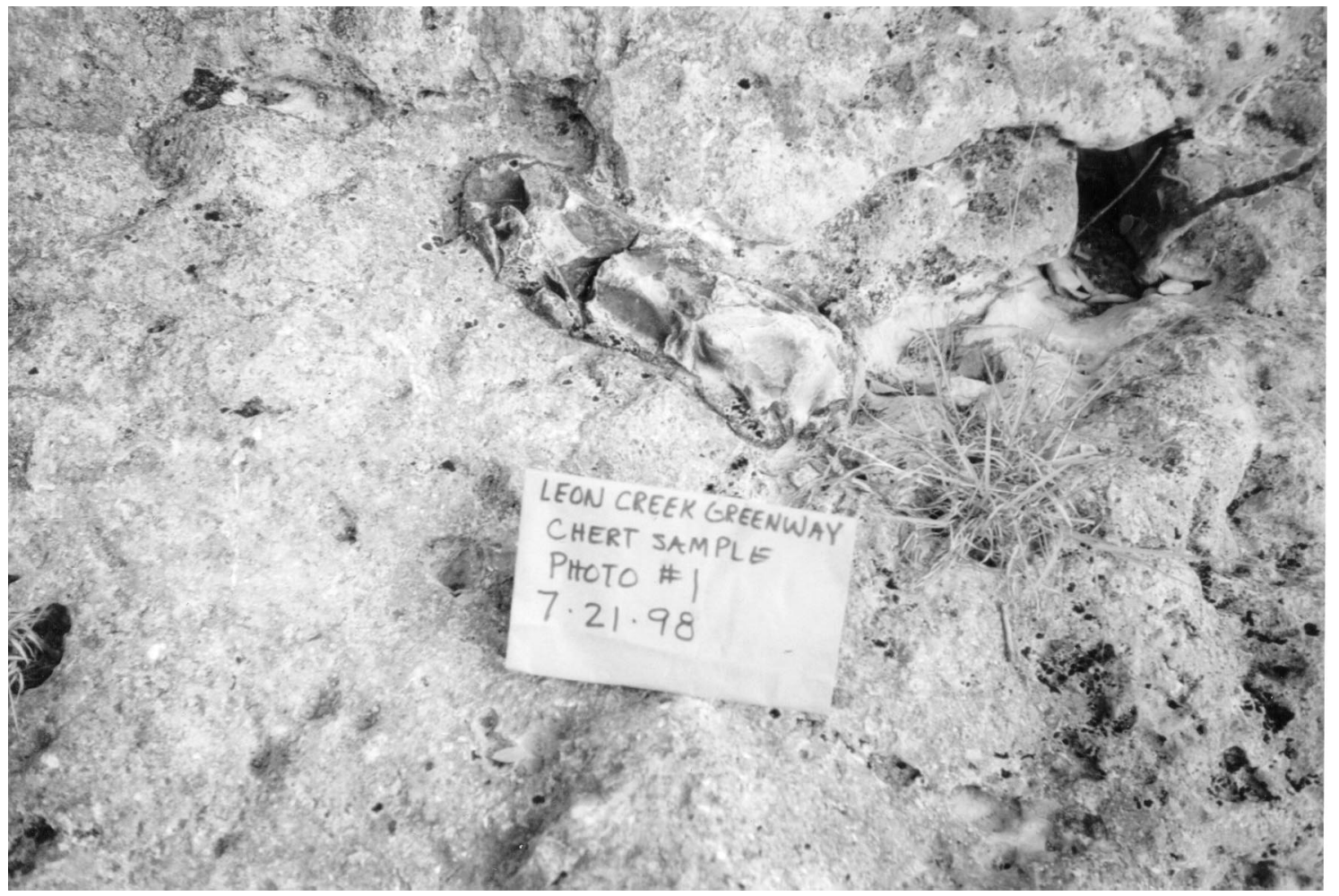

Figure 13. Chert outcrops in Leon Creek channel. 


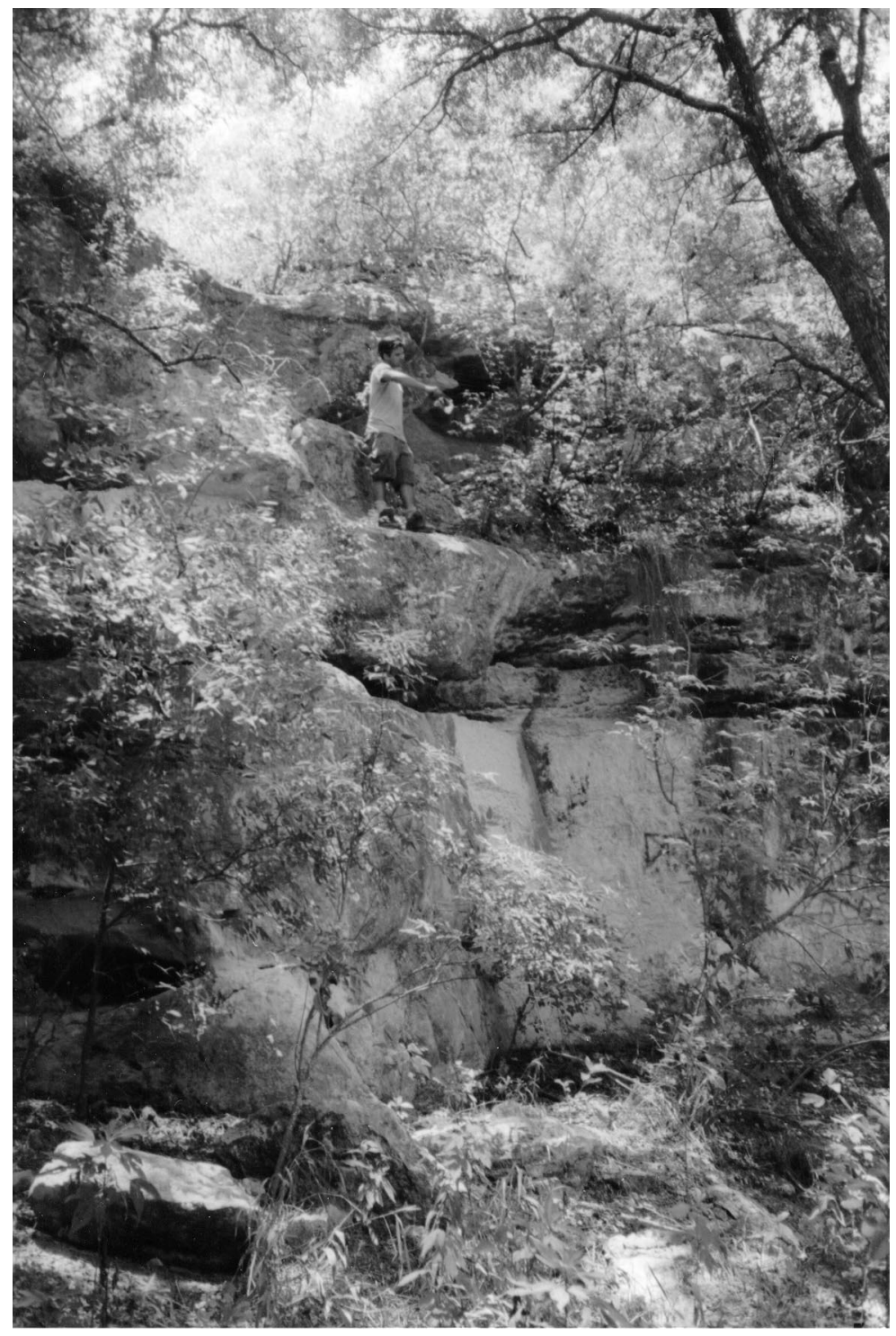

Figure 14. Rock cliffs in Parcel 1.

collected from the talus slope. During the current project it was reasonably safe to investigate limestone bluffs and rockshelters in Parcel 1 and Parcel 4 to a height of approximately 30 feet (Figure 14). Some areas were inaccessible and unsafe. Neither 41BX61 nor 41BX62 was relocated during the current project. Only modern cultural material associated with urban use was observed.

\section{Summary and Recommendations}

The pedestrian survey along Leon Creek occurred largely within the active floodplain. T1 terrace deposits with the potential for containing significant cultural resources comprised a minor component of the total project area. When T1 terrace deposits were encountered, they often occurred as narrow bands bordered by privacy fences and housing developments. These $\mathrm{T} 1$ terraces - when shovel tested-frequently showed evidence of disturbance associated with landscaping and housing construction.

Three newly identified archaeological sites were documented. Two sites, 41BX1301 and 41BX1303, were identified near the base of T1 terrace slopes. With the exception of surface collecting the artifacts for chert sourcing information and comparative artifact data analysis, interpretation of these sites is extremely limited due to the paucity of materials, and to the secondary context in which they were found. Sites 41BX1301 and 41BX1303 (within the current project boundary) do not represent intact deposits and as such are not recommended for State Archaeological Landmark status nor are they recommended as eligible for inclusion in the National Register of Historic Places.

Site 41BX1302, which occupies a relatively large T1 terrace, contains intact and significant cultural materials. The site appears to be comprised of at least two components; an upper deposit, observed on the surface and to a depth of $50 \mathrm{~cm}$ (bottom of shovel tests), and a lower buried component; observed in the profile of an erosional feature at one meter below the surface. Artifacts from both components indicate that the site represents a campsite where processing of foodstuffs occurred. Based on the recovery of the Marcos dart point from the surface of 41BX1302, the upper component may date to perhaps the Late and/or Transitional Archaic Period. The lower buried deposit appears to represent a discrete component; however, further work will be needed to substantiate this claim. Site 41BX1302 has the potential for providing important information on the prehistory of the area. The upper deposit has been impacted in some areas by the construction of houses adjacent to and west of the site 
but it is difficult to assess the depth of this disturbance across the site without additional work. The buried component is intact; unfortunately, it is undergoing a high degree of erosion during heavy rains due to its exposure within the erosional cut. The upper deposit is also affected by erosional processes but given its location on a nearly level terrace, combined with adequate ground cover, erosion is less problematic. One very important issue concerning 41BX1302 is the fact that the site has been discovered by pot hunters and is currently subjected to looting activities. It is strongly suggested that $41 \mathrm{BX} 1302$ be af- forded some course of protection in order to halt the looting activities occurring at the site. It is recommended that 41BX1302 has the potential for listing in the National Register of Historic Places and that this site should be avoided during the development of the Leon Creek Greenway. We conclude that no significant cultural deposits will be affected in Parcel's 1 through 5 during the development of the Leon Creek Greenway provided that site 41BX1302 is completely avoided. If complete avoidance of this site is not possible, then it should be tested for significance prior to any ground-disturbing activities. 


\section{Appendix 1. \\ Lithic Analysis of Bifaces, Projectile Points, and Complete Flakes from Sites 41BX1301 and 41BX1302}

\begin{tabular}{|c|c|c|c|c|c|c|c|c|c|c|c|c|c|c|c|}
\hline \multicolumn{16}{|c|}{ Bifaces from Site 41BX1302 } \\
\hline Provenience & & & Raw & Material & & & & & Biface A & ttributes & & & & & \\
\hline Unit Type & $\mathrm{Lvl}$ & Scrn & $\begin{array}{l}\text { Mat. } \\
\text { Type }\end{array}$ & Grain Size & Burn & Cortex & Length & Width & Thickness & \begin{tabular}{|l} 
Tool \\
Comp.
\end{tabular} & Blank Type & $\begin{array}{l}\text { Stage } \\
\text { Reduc }\end{array}$ & Shape & \begin{tabular}{|l|} 
Break \\
Type
\end{tabular} & $\begin{array}{l}\text { Tool } \\
\text { Recyc } \\
\end{array}$ \\
\hline Shovel Test 66 & 4 & $1 / 4^{\prime \prime}$ & chert & $\begin{array}{l}\text { fine (no } \\
\text { inclusions) }\end{array}$ & no & absent & $26 \mathrm{~mm}$ & $30 \mathrm{~mm}$ & $5 \mathrm{~mm}$ & medial & Indet & Late & Indet & Indet & yes \\
\hline Back Dirt/Looter's & no & no & chert & \begin{tabular}{|l} 
fine (no \\
inclusions)
\end{tabular} & no & absent & $35 \mathrm{~mm}$ & $38 \mathrm{~mm}$ & $9 \mathrm{~mm}$ & proximal & Indet & Late & Triangular & Indet & no \\
\hline Back Dirt/Looter's & no & no & chert & $\begin{array}{l}\text { fine (no } \\
\text { inclusions) }\end{array}$ & no & absent & $43 \mathrm{~mm}$ & $44 \mathrm{~mm}$ & $9 \mathrm{~mm}$ & medial & Indet & Late & Indet & Manuf & no \\
\hline
\end{tabular}

\begin{tabular}{|c|c|c|c|c|c|c|c|c|c|c|c|}
\hline \multicolumn{12}{|c|}{ Projectile Points from 41BX1302 } \\
\hline Provenience & & & \multicolumn{2}{|c|}{ Raw Material } & \multicolumn{7}{|c|}{ Projectile Point Attributes } \\
\hline Unit Type & Lvl & Scrn & $\begin{array}{l}\text { Mat. } \\
\text { Type } \\
\end{array}$ & Grain Size & Burn & $\begin{array}{l}\text { Projectile } \\
\text { SubGroup }\end{array}$ & Projectile Type & Serr. & Bevel & Complete & Break Type \\
\hline $\begin{array}{l}\text { Ground Surface/Near } \\
\text { Shovel Test } 53\end{array}$ & no & no & chert & $\begin{array}{l}\text { fine (no } \\
\text { inclusions) }\end{array}$ & no & Dart Point & Marcos & absent & absent & proximal & Use \\
\hline $\begin{array}{l}\text { Confluence of Creek } \\
\text { and Erosional Feature }\end{array}$ & no & no & chert & $\begin{array}{l}\text { fine (no } \\
\text { inclusions) }\end{array}$ & no & Dart Point & Ensor & absent & absent & proximal & $\begin{array}{l}\text { Use/Resharp- } \\
\text { ening }\end{array}$ \\
\hline $\begin{array}{l}\text { Ground Surface/In } \\
\text { Northern Dirt Road }\end{array}$ & no & no & chert & $\begin{array}{l}\text { fine (no } \\
\text { inclusions) }\end{array}$ & no & Dart Point & Indeterminate & absent & absent & distal & Manufacturing \\
\hline
\end{tabular}

\begin{tabular}{|c|c|c|c|c|c|c|c|c|c|c|}
\hline \multicolumn{11}{|c|}{ Debitage from Site 41BX1302 } \\
\hline Provenience & & & \multicolumn{3}{|c|}{ Raw Material } & \multicolumn{5}{|c|}{ Debitage Attributes } \\
\hline Unit Type & Lvl & Scrn & $\begin{array}{l}\text { Mat. } \\
\text { Type }\end{array}$ & $\begin{array}{l}\text { Internal } \\
\text { Fracture }\end{array}$ & Grain Size & $\begin{array}{l}\text { Maximum } \\
\text { Dimension }\end{array}$ & $\begin{array}{l}\text { Platform } \\
\text { Faceting }\end{array}$ & $\begin{array}{l}\text { Dorsal } \\
\text { Cortex }\end{array}$ & Flake Type & $\begin{array}{l}\text { Stream } \\
\text { Damage }\end{array}$ \\
\hline Shovel Test 53 & 1 & $1 / 4^{\prime \prime}$ & chert & absent & $\begin{array}{l}\text { fine (no } \\
\text { inclusions) }\end{array}$ & $1-2 \mathrm{~cm}$ & single & tertiary & Indet & no \\
\hline Shovel Test 62 & 1 & $1 / 4^{\prime \prime}$ & chert & absent & \begin{tabular}{|l} 
fine (no \\
inclusions)
\end{tabular} & $1-2 \mathrm{~cm}$ & single & tertiary & $\begin{array}{l}\text { Platform/C } \\
\text { ore Prep }\end{array}$ & no \\
\hline Shovel Test 64 & 2 & $1 / 4^{\prime \prime}$ & chert & absent & $\begin{array}{l}\text { fine (with } \\
\text { inclusions) }\end{array}$ & $3-4 \mathrm{~cm}$ & three + & tertiary & \begin{tabular}{|l|} 
Biface \\
Thinning \\
\end{tabular} & no \\
\hline Shovel Test 64 & 3 & $1 / 4^{\prime \prime}$ & chert & absent & $\begin{array}{l}\text { fine (with } \\
\text { inclusions) }\end{array}$ & $4-5 \mathrm{~cm}$ & Corticate & secondary & $\begin{array}{l}\text { Platform/C } \\
\text { ore Prep }\end{array}$ & no \\
\hline & & & & & & & & & & \\
\hline
\end{tabular}

\begin{tabular}{|c|c|c|c|c|c|c|c|c|c|c|}
\hline \multicolumn{11}{|c|}{ Debitage from Site 41BX1301 } \\
\hline Provenience & & & \multicolumn{3}{|c|}{ Raw Material } & \multicolumn{5}{|c|}{ Debitage Attributes } \\
\hline Unit Type & $\mathrm{Lvl}$ & Scrn & $\begin{array}{l}\text { Mat. } \\
\text { Type }\end{array}$ & $\begin{array}{l}\text { Internal } \\
\text { Fracture }\end{array}$ & Grain Size & $\begin{array}{l}\text { Maximum } \\
\text { Dimension }\end{array}$ & $\begin{array}{l}\text { Platform } \\
\text { Faceting }\end{array}$ & \begin{tabular}{|l} 
Dorsal \\
Cortex \\
\end{tabular} & $\begin{array}{l}\text { Flake } \\
\text { Type }\end{array}$ & $\begin{array}{l}\text { Stream } \\
\text { Damage }\end{array}$ \\
\hline Shovel Test 44 & 1 & $1 / 4^{\prime \prime}$ & chert & absent & \begin{tabular}{|l} 
fine (no \\
inclusions)
\end{tabular} & $1-2 \mathrm{~cm}$ & single & tertiary & $\begin{array}{l}\text { Uniface } \\
\text { Manuf/ } \\
\text { Resharp }\end{array}$ & no \\
\hline
\end{tabular}




\section{References Cited}

Arbingast, S. A., L. Kennamer, R. Ryan, J. Buchanan, W. Hezlep, L. Ellis, T. Jordan, C. Granger, and C. Zlatkovich 1973 Atlas of Texas. Bureau of Buisness Research, The University of Texas at Austin.

Bannon, J. F.

1979 The Spanish Borderlands Frontier 1513-1821. University of New Mexico Press, Albuquerque.

Barnes, V. E.

1983 Geologic Atlas of Texas: San Antonio Sheet. Bureau of Economic Geology, The University of Texas at Austin.

Black, S. L.

1989a Central Texas Plateau Prairie. In From the Gulf Coast to the Rio Grande: Human Adaptation in Central, South and Lower Pecos Texas, edited by T. R. Hester, S.L. Black, D. G. Steele, B. W. Olive, A. A. Fox, K. J. Reinhard, and L. C. Bement, pp. 17-38. Research Series No. 33. Arkansas Archeological Survey, Fayetteville.

1989b South Texas Plain. In From the Gulf Coast to the Rio Grande: Human Adaptation in Central, South and Lower Pecos Texas, edited by T. R. Hester, S. L. Black, D. G. Steele, B. W. Olive, A. A. Fox, K. J. Reinhard, and L. C. Bement, pp. 39-62. Research Series No. 33. Arkansas Archeological Survey, Fayetteville.

Blair, W. F.

1950 The Biotic Provinces of Texas. The Texas Journal of Science 2(1):93-117.

Bruseth, J. E.

1992 Artifacts of the De Soto Expedition: The Evidence from Texas. Bulletin of the Texas Archeological Society 63:67-97.

Collins, M. B., and R. A. Ricklis

1994 Cultural Background. In Archaic and Late Prehistoric Human Ecology in the Middle Onion Creek Valley, Hays County, Texas, edited by M. B. Collins and R. A. Ricklis, 1:11-26. Studies in Archeology 19. Texas Archeological Research Laboratory, The University of Texas at Austin.

Collins, M. B.

1995 Forty Years of Archeology in Central Texas. Bulletin of the Texas Archeological Society 66:361-400.

Corps of Engineers-Fort Worth District

1971 Flood Plain Information Leon Creek, San Antonio, Texas. Corps of Engineers, Fort Worth, Texas.

Ricklis, R. A.

1994 Toyah Components: Evidence For Occupation in the Project Area During the Latter Part of the Late Prehistoric Period. In Archaic and Late Prehistoric Human Ecology in the Middle Onion Creek Valley, Hays County, Texas, edited by M. B. Collins and R. A. Ricklis, 1:207-315. Studies in Archeology 19. Texas Archeological Research Laboratory, The University of Texas at Austin. 
Taylor, F. B., R. B. Hailey, and D. L. Richmond

1991 Soil Survey of Bexar County, Texas. Soil Conservation Service, U.S. Department of Agriculture, Washington D.C.

Tennis, C. L.

1996 Archaic Land Use of Upper Leon Creek Terraces: Archaeological Testing in Northern Bexar County, Texas. Archaeological Survey Report, No. 234. Center for Archaeological Research, The University of Texas at San Antonio.

Trierweiler, W. N., G. L. Ellis, and J. M. Quigg

1995 Research Context for Site Testing. In NRHP Significance Testing of 57 Prehistoric Archaeological Sites on Fort Hood, Texas. Archaeological Resource Management Series Research Report No. 34. Vol 1:27-38. United States Army, Fort Hood.

Weir, F. A.

1997 Archeological and Historical Survey of the Proposed Bandera Commons Apartments, San Antonio, Bexar County, Texas. Weir Enterprises, Austin.

1976 The Central Texas Archaic. Unpublished Ph. D. dissertation. Washington State University, Pullman. 